Holzer, K. (1975): Genetics of Pinus cembra L. Anales Forestales, 6 / 5, Zagreb, $158 \mathrm{p}$.

Lambeth, C. C., J. P. van BuiJtenen and S. Duke (1983): Early selection is effective in 20-year-old genetic tests of loblolly pine. Silvae Genetica 32 (5-6): 210-213.

Lowe, W. J. and J. P. VAN BUIJTENEN (1989): The incorporation of early testing procedures into an operational tree improvement program. Silvae Genetica 38 (5-6): 242-250.

Mirov, N. T. (1967): The genus Pinus. New York, Ronald Press Comp., 602 p.

OARCEA, Z. (1966): Contributii la cunoasterea si vegetarii pinului cembra in Retezat. Revista Padurilor 9: 495-497.

RIKLI, M. (1909): Die Arve in the Schweiz. Denkschrift Naturf. Gesellschaft 44, 455 p.
SchmidT, W. C. (1994): Distribution of stone pines, p. 1. In: Schmidt, W. C and Holtmeier, F. K. (Eds) Proc. Int. Workshop on Sub-alpine Stone Pines and Their Environment, Intermountain Res. Station, Tech. Rep. 309.

Tataranu, I. D. and C. Costea (1952): Un arbore de interes forestier: Pinus cembra. Revista Padurilor 11: $3-14$.

van BuiJtenen, J. P. and J. L. Yeiser (1989): Exercises in quantitative genetics of forest trees. Student Book, Texas A\&M University106 p.

VIERSMA, J. H. (1962): Enkete kwantitatieve aspecten van het exotenvraagstuk. Nederlands Bosbouw Tijtschrift 34 (5): 175-184.

Zobel, B. and J. TALBERT (1984): Applied forest tree improvement. John Wiley \& Sons, New York, 505 p.

\title{
Comparative Analysis of Karyotypes from the Strezelecki Ranges Race of the Complex Eucalyptus globulus Labill. ssp. globulus (Myrtaceae) and a Population in Central-Southern Chile
}

\author{
By J. Espejo CARDemil ${ }^{1)}$ and C. BAeza Perry ${ }^{2), *}$
}

(Received 12 $2^{\text {th }}$ April 2006)

\begin{abstract}
Summary
This study presents information on karyotypes of the Strezelecki Ranges race, referred to in previous studies as Jeerelangs (Victoria, Australia), of the complex Eucalyptus globulus. ssp globulus and another from CentralSouthern Chile (Contulmo). The chromosomes counted $(2 \mathrm{n}=22)$ are fairly small-sized and found within the size ranges reported by other authors. The chromosome measurements, done with the Micromeasure program, indicate that the Strezelecki Ranges lineage has a relatively large genome (Total Chromosome Length $=8.94 \%$ ) as compared to measurements of local lineages (Chile). This could be explained by genetic recombinations resulting from the successive hybridizations reported for this race. The data obtained for both lineages reveal a set of markedly metacentric chromosomes with a centromeric index between 0.44 and 0.46 .
\end{abstract}

Key words: Eucalyptus globulus, Myrtaceae, karyotype, chromosomes, land race, Chile, Australia.

\section{Introduction}

The study of karyotypes is a valuable tool for comparing species and discriminating between populations (MATSumoto et al., 2000; Schrader et al., 2000;

\footnotetext{
1) Programa Magíster en Ciencias Forestales. Universidad de Concepción.

2) Departamento de Botánica. Universidad de Concepción.

*) Corresponding Author: Telephone \#: (56-43) 220-3879; Fax \#: (56-43) 224-7060; Email: cbaeza@udec.cl.
}

Schrader et al., 2003). STEBbins (1971) indicated that the majority of this woody angiosperm's chromosomes are very small and that small differences exist between the species within the genus. The report of the Eucalyptus globulus Labill. chromosome recount done by BoLKHOVsKiKH et al., (1969) showed that $82 \%$ of the counts done for the species of this genus had a karyotype of $2 \mathrm{n}=22$ chromosomes. In a cytological study, RYE (1979) reported that up to $90 \%$ of the species studied have the same number of chromosomes. Eucalyptus has been described as a very large genus, with over 700 species (PoKE et al., 2006). In cline variations and hybridizations are very common and can be verified within the subgenera (PRYOR, 1976).

The first systematic cytological studies of Eucalyptus globulus pollen grains began in the 1930s (MCAULAY et al., 1936; MCAULAY and CRUICKSHANK, 1937); these studies reported a haploid number for the species of $\mathrm{n}=11$. Later, BEDI (1989) and MoRA et al., (2005) carried out new chromosome counts for this species using material taken from root tips. The latter authors also analyzed the E. globulus karyotype and found that the chromosomes fluctuated between $1.42 \pm 0.4 \mu \mathrm{m}$ in length.

No karyotype characterization studies have been done to discriminate between $E$. globulus sub-species and races, mostly because of the methodological complexity of obtaining metaphase plates from the very small chromosomes $(<2 \mu \mathrm{m})$ that characterize this species and genus (Atchinson, 1947; RYE, 1979; HAQUe, 1984; HARBARD, 1995, 1996; MATSUMOTO et al., 2000). JoRDAN et al. 


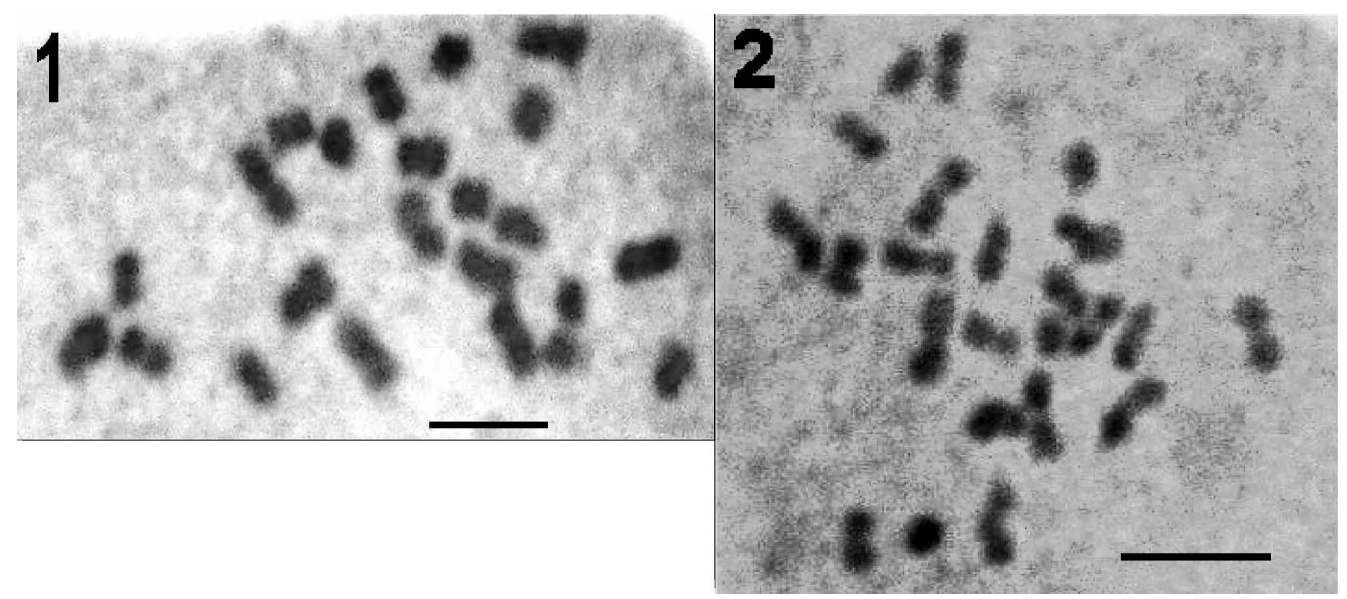

Figure 1. - Metaphase chromosomes of Eucalyptus globulus $(2 \mathrm{n}=22)$ from Jeerelangs seeds.

Figure 2. - Metaphase chromosomes $(2 \mathrm{n}=22)$ from Contulmo seeds; Scale of bar is $5 \mu \mathrm{m}$.

(1993) and DutKowski and PotTs (1999) indicated that the Eucalyptus globulus complex (subgenus Symphyomyrtus) is made up of 13 races and 20 sub-races. The Strezelecki Ranges race is one member of the E. globulus complex. Originating in Victoria, Australia, this race includes individuals integrated through hybridization or introgression. Trees of the Strezelecki Ranges can be clearly and precisely distinguished from trees of other origins using a series of morphological attributes determined by DutKowskY and Роттs et al., (2004). Because of their good growth, survival rates, and wood properties, the Jeerelangs and Jeerelangs North families of the Strezelecki Ranges race have been used for infusions or as base populations for some genetic improvement programs. Thus, it is common to find these families ranked in the upper quartile (POTTS and JoRDAN, 1993; GRIFFIN, 2001; SANHUEZA et al., 2001; GALLO, 2004).

The present work sets forth a detailed cytological comparison of two Eucalyptus globulus populations: Chile and Australia. The purposes of this work are (1) to determine the statistical parameters of the chromosome size and the karyotypes and (2) to identify possible differences between the karyotypes studied.

\section{Materials and Methods}

\section{Plant material}

Two populations of Eucalyptus globulus Labill. (Myrtaceae) were analyzed. Seeds were collected in Chile, Region VIII: Contulmo (37 $47^{\circ}$ S; $\left.73^{\circ} 66^{\prime} \mathrm{W}\right)$

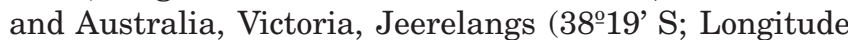
$\left.146^{\circ} 33^{\prime} \mathrm{W}\right)$.

Fifteen seeds were sown from ten trees of each location. Eucalyptus seedlings were grown on water-moistened filter paper at $24^{\circ} \mathrm{C}$. Once their roots reached 1 to $2 \mathrm{~cm}$ long, they were excised and pre-treated with 8hydroxyquinoline solution $(2 \mathrm{mM}$ aqueous solution at $4^{\circ} \mathrm{C}$ for $24 \mathrm{~h}$ ), fixed in a freshly prepared mixture of

Table 1. - Results of measurements of ten metaphasic plates of Eucalyptus globulus, Jeerelangs (Australia).

\begin{tabular}{|c|c|c|c|c|c|c|}
\hline $\begin{array}{c}\text { Chromosome } \\
\text { (pair) }\end{array}$ & $\begin{array}{c}\text { Long arm (\%) } \\
+ \text { Sd }\end{array}$ & $\begin{array}{l}\text { Short Arm } \\
(\%)+\text { Sd }\end{array}$ & $\begin{array}{c}\text { Total } \\
\text { Length } \\
(\%)\end{array}$ & $\begin{array}{l}\text { Arm } \\
\text { Ratio } \\
(\mathrm{L} / \mathrm{S})\end{array}$ & Index & $\begin{array}{c}\text { Chromosome } \\
\text { Type }\end{array}$ \\
\hline 1 & $2.03 \pm 0.55$ & $1.58 \pm 0.29$ & 3.61 & 1.29 & 0.45 & $\mathrm{~m}$ \\
\hline 2 & $1.82 \pm 0.49$ & $1.47 \pm 0.32$ & 3.29 & 1.24 & 0.46 & $\mathrm{~m}$ \\
\hline 3 & $1.76 \pm 0.41$ & $1.34 \pm 0.35$ & 3.10 & 1.31 & 0.44 & $\mathrm{~m}$ \\
\hline 4 & $1.71 \pm 0.43$ & $1.28 \pm 0.27$ & 2.99 & 1.34 & 0.44 & $\mathrm{~m}$ \\
\hline 5 & $1.60 \pm 0.42$ & $1.26 \pm 0.28$ & 2.86 & 1.27 & 0.45 & $\mathrm{~m}$ \\
\hline 6 & $1.51 \pm 0.36$ & $1.18 \pm 0.21$ & 2.69 & 1.28 & 0.45 & $\mathrm{~m}$ \\
\hline 7 & $1.41 \pm 0.32$ & $1.10 \pm 0.20$ & 2.51 & 1.28 & 0.45 & $\mathrm{~m}$ \\
\hline 8 & $1.31 \pm 0.31$ & $1.06 \pm 0.22$ & 2.37 & 1.24 & 0.45 & $\mathrm{~m}$ \\
\hline 9 & $1.30 \pm 0.30$ & $0.99 \pm 0.20$ & 2.29 & 1.31 & 0.44 & $\mathrm{~m}$ \\
\hline 10 & $1.22 \pm 0.28$ & $0.96 \pm 0.22$ & 2.18 & 1.27 & 0.44 & $\mathrm{~m}$ \\
\hline 11 & $1.13 \pm 0.28$ & $0.84 \pm 0.13$ & 1.34 & 1.34 & 0.44 & $\mathrm{~m}$ \\
\hline
\end{tabular}


Table 2. - Results of measurement of ten metaphasic plates of Eucalyptus globulus, Contulmo (Antiquina. VIII Region, Chile).

\begin{tabular}{|c|c|c|c|c|c|c|}
\hline $\begin{array}{c}\text { Chromosome } \\
\text { (pair) }\end{array}$ & $\begin{array}{c}\text { Long arm (\%) } \\
+ \text { Sd }\end{array}$ & $\begin{array}{l}\text { Short Arm } \\
(\%)+\text { Sd }\end{array}$ & $\begin{array}{c}\text { Total } \\
\text { Length } \\
(\%)\end{array}$ & $\begin{array}{l}\text { Arm } \\
\text { Ratio } \\
(\mathrm{L} / \mathrm{S})\end{array}$ & Index & $\begin{array}{c}\text { Chromosome } \\
\text { Type }\end{array}$ \\
\hline 1 & $1.66 \pm 0.12$ & $1.38 \pm 0.18$ & 3.04 & 1.22 & 0.45 & $\mathrm{~m}$ \\
\hline 2 & $1.50 \pm 0.13$ & $1.17 \pm 0.20$ & 2.67 & 1.30 & 0.44 & $\mathrm{~m}$ \\
\hline 3 & $1.40 \pm 0.14$ & $1.09 \pm 0.20$ & 2.49 & 1.30 & 0.43 & $\mathrm{~m}$ \\
\hline 4 & $1.32 \pm 0.14$ & $1.00 \pm 0.21$ & 2.32 & 1.35 & 0.43 & $\mathrm{~m}$ \\
\hline 5 & $1.25 \pm 0.11$ & $0.95 \pm 0.19$ & 2.20 & 1.33 & 0.43 & $\mathrm{~m}$ \\
\hline 6 & $1.23 \pm 0.16$ & $0.92 \pm 0.10$ & 2.15 & 1.31 & 0.43 & $\mathrm{~m}$ \\
\hline 7 & $1.13 \pm 0.10$ & $0.89 \pm 0.16$ & 2.02 & 1.29 & 0.44 & $\mathrm{~m}$ \\
\hline 8 & $1.08 \pm 0.13$ & $0.85 \pm 0.17$ & 1,93 & 1.29 & 0.44 & $\mathrm{~m}$ \\
\hline 9 & $1.05 \pm 0.13$ & $0.89 \pm 0.16$ & 1.94 & 1.29 & 0.46 & $\mathrm{~m}$ \\
\hline 10 & $1.03 \pm 0.13$ & $0.73 \pm 0.19$ & 1.76 & 1.43 & 0.41 & $\mathrm{~m}$ \\
\hline 11 & $0.94 \pm 0.10$ & $0.57 \pm 0.13$ & 1.51 & 1.65 & 0.38 & $\mathrm{~m}$ \\
\hline
\end{tabular}

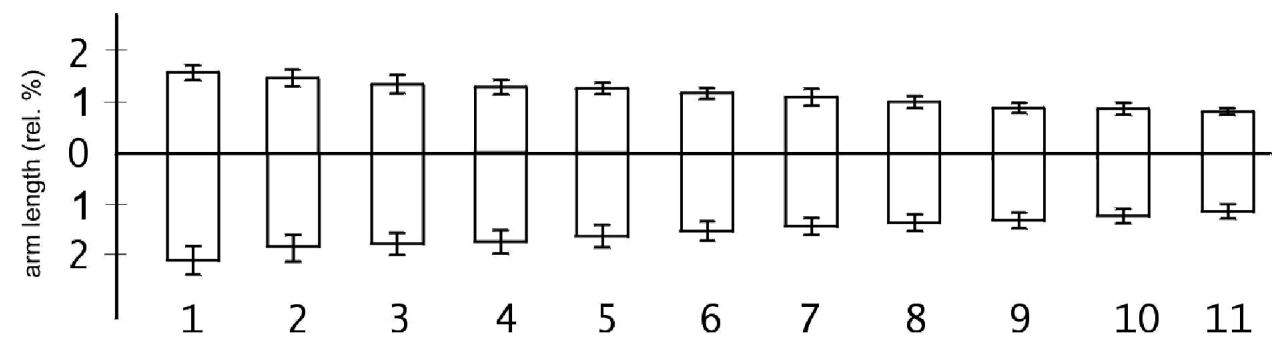

Figure 3. - Ideogram of Eucalyptus globulus (Jeerelangs). The values are expressed in percentages (\%) according to Table 1.

absolute ethanol/glacial acetic acid (3:1) for $24 \mathrm{~h}$, and stored in $70 \%$ ethanol at $-20^{\circ} \mathrm{C}$. Later, the roots were treated with hydrochloric acid $(0.05 \mathrm{~N})$ for $25 \mathrm{~min}$ at $38^{\circ} \mathrm{C}$. After rinsing with distilled water, they were crushed in a drop of acetic orcein (1\%).

\section{Microscope Screening and Chromosome Measurements}

The metaphase plates were photographed with a Zeiss Axioskop microscope. The chromosomes were measured with the help of the computer program "MicroMeasure 3.3" (REEVES, 2001) and classified according to the ratio of the arms (long arm/short arm; modified from LEVAN et al., 1964) given the position of the centromere: $1.0-1.7$ (metacentric; m), 1.7-3.0 (submetacentric; sm), 3.0-7.0

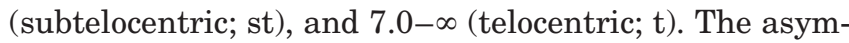
metry index of the karyotype was determined (AsI \%) for the populations analyzed (10 metaphase plates) using the formula described by ARANO and SAITO (1980) and $\mathrm{R}$ (longest pair/shortest pair). For a better comparison, the length of each chromosome was calculated as a percentage of the total genomic length of the corresponding set of diploid chromosomes. Corel Draw (version 8.0) was used for the graphic representation of the chromosome set (ideogram) and Paint Shop Pro 7 was used to analyze the photos.
We compared specimens from Jeerelangs and Contulmo by making direct calculations from the published ideogram (MoRA et al., 2005), R, and the karyotypic asymmetry index of ARANO and SAITO (AsI \%).

\section{Results}

Both populations of Eucalyptus globulus studied herein had a karyotype of $2 n=22$, with 11 metacentric chromosome pairs. The results of the chromosome measurements are summarized in Tables 1 and 2 and Figures 3 and 4 (ideograms).

The radius of the longest pair divided by the radius of the shortest pair (R) was 2.0 for the Jeerelangs population and 1.8 for the Contulmo population. The asymmetry index of the karyotype (AsI \%) was 57.5 for the Jeerelangs population and 56.2 for the Contulmo population (Table 3).

\section{Discussion}

Both Jeerelangs and Contulmo populations of E. globulus have chromosome counts of $2 \mathrm{n}=22$, and their very small, clustered chromosomes make counting and measuring difficult. This is the first report on the number of 


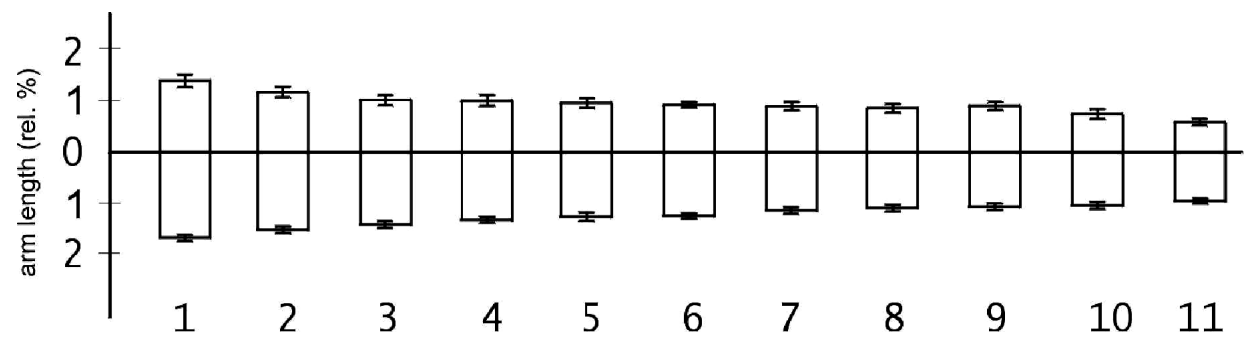

Figure 4. - Ideogram of Eucalyptus globulus (Contulmo). The values are expressed in percentages (\%) according to Table 2.

Table 3. - Comparison of ARANO and SAITO (1980) Index and R for Eucalyptus globulus of three provenances.

\begin{tabular}{cccc}
\hline Species & Provenance & $\begin{array}{c}\text { ARANo and } \\
\text { SAITo Index } \\
(\%)\end{array}$ & R \\
\hline E. globulus & Jeerelangs, (Victoria). Australia & 57.5 & 2.0 \\
E. globulus & Contulmo, (Antiquina). Chile & 56.2 & 1.8 \\
E. globulus* & Cañete, (Los Hermanos). Chile & 54.2 & 1.8 \\
\hline
\end{tabular}

* Data from Cañete was extrapolated from the idiograms of MORA et al. (2005).

chromosomes in these populations. McAULAY and CRUICKSHANK (1937) stated that, both in metaphase and anaphase, the $E$. globulus chromosomes are very small, frequently clustered and, in some cases, suspicious specters are observed due to an excess of stain. This study was no exception; a very low percentage $(<5 \%)$ of the metaphases studied revealed sufficient information to characterize each of the chromosomes.

Matsumoto et al., (2000) indicated that Eucalyptus has metacentric chromosomes, except for $E$. saligna (Symphyomyrtus), in which chromosomes 10 and 11 are submetacentric. The chromosomes in both the Jeerelangs and Contulmo populations were metacentric. This is further supported by the karyotype assymetry index of ARANO and SAITO (1980) for Jeerelangs (57.5) and Contulmo (56.2). MorA et al. (2005) indicated that chromosome 9 is submetacentric for $E$. globulus from Cañete, Fundo Los Hermanos, a site near Contulmo. Unfortunately, the authors do not give statistical data on the measurements of each chromosome and the photograph included does not clarify their statement. According to our study, it is highly probable that the majority of the races in the $E$. globulus complex have metacentric chromosomes.

The comparative analysis (Table 3) of E. globulus from Jeerelangs (Victoria, Australia), Contulmo (Antiquina), and Cañete was done using the relationship between the longest and shortest chromosome pairs (R) and the assymetry karyotype index of ARANO and SAITO (1980) and does not reveal intraspecific differences that allow discrimination of the Jeerelangs provenance from the other two.

EATON and MAFFIOLETI (1995) performed isoenzymatic studies in an attempt to establish the origin of the
E. globulus populations introduced in Chile at the beginning of the nineteenth century. These studies suggest that the Chilean populations originated in southern Tasmania. LOPEz et al., (2001) confirms this in a study that reported close affinities between the Chilean land race and native stands in Tasmania.

The total size of the haploid genome (TCL) for Jeerelangs was $57.65 \pm 8.59 \mu \mathrm{m}$ and for Contulmo $48.72 \pm$ $4.11 \mu \mathrm{m}$. Moreover, differences were observed in the relative size of the chromosomes, with the Jeerelangs chromosomes being larger than those from Contulmo. The greater quantity of nuclear material could be the product of the gene recombinations ("introgressions") reported for this race (JORDAN et al., 1993; DuTKOwsKY and PotTs, 1999). According to STEBBINs (1971), differences in chromosome sizes reflect differences in genes or the synthetic proteins of individuals resulting from gene duplications. LEVIN (2002) indicated that genome variation is accompanied by variations in the size of the introns, which appear not to code inside the plant genes and vary widely among angiosperms. Given the low percentages of good quality metaphase plates, there is still no ad-hoc protocol that allows working more efficiently and precisely.

Cytogenetic techniques (FISH and GISH) result in clearer, more exact information, a basic requirement for comparative studies related to the evolution of the Eucalyptus karyotype.

\section{Acknowledgments}

The authors acknowledge Forestal Mininco S.A. for supporting this Master's Thesis and the Instituto Forestal, who provided the seeds from Contulmo. We are very 
thankful to Gustavo Lopez, Greg Dutkowsky, ReBeca SANHUEZA, and ViCTOR SiERRA for suggestions, comments, and corrections on this manuscript.

\section{References}

Arano, H. and H. SAIto (1980): Cytological studies in family Umbelliferae 5 . Karyotypes of seven species in subtribe Seselinae. La Kromosomo 2: 471-480.

Atchinson, E. (1947): Chromosome Numbers in the Myrtaceae. Am. J. Bot. 34: 159-164.

BEDy, Y. S. (1989): Karyological Studies in Eucalyptus L. Her. Plants Science Research in India. Eds. M. L. Trivedi, B. S. Gill \& S. S. Sainl. 391-397.

BolkhovskikH, Z., V. GRIF, M. MATVEJeva and O. ZAKHARYEVA (1969): Chromosome Numbers of Flowering Plants. Academic of Sciences of the USSR. V. L. Komarov Botanical Institute.

Dutkowsky, G. W. and B. M. Potts (1999): Geographic Patterns of Genetic Variation in Eucalyptus globulus ssp globulus and Revised Racial Clasification. Austral. J. Bot. 47: 237-263.

EATON, L. and H. MAFFiLleti (1995): Análisis Variabilidad Procedencias y Arboles individuales de Eucalyptus globulus. Informe Técnico Silvicultura. Santiago. INFOR.

GALlo, L. A. (2004): Evaluación Preliminar de Procedencias de Eucalyptus globulus. En Actas del Primer Simposio Iberoamericano de Eucalyptus globulus. Uruguay.

GRIFFIN, A. R. (2001): Deployment Decisions - Capturing the Benefits of Tree Improvement with Clones and Seedlings. Actas del Simposio IUFRO, "Desarrollando el Eucalypto para el Futuro", Valdivia, Chile.

HAQUe, M. S. (1984): Chromosome morphology in four species of Eucalyptus L'Herit. Cytologia 49: 547-550.

HARBARD, J. L. (1995): Methodologies for Obtaing a Chromosome Count in Eucalyptus ssp. Internal Report, Shell Forestry Unit, HRI, East Malling.

HARBARD, J. L. (1996): Chromosome. Studies in Regenerants Eucalyptus and Eucalyptus Hybrids. Internal Report, Shell Forestry Unit, HRI, East Malling

Jordan, G. J., B. M. PotTs, J. B. KirkPATRICK and C. GARDINER (1993): Variation in the Eucalyptus globulus Complex Revisited. Austral. J. Bot. 41: 763-785.

Levan, A., K. Fredga and A. SANDBERg (1964): Nomenclature for centromeric position on chromosomes. Hereditas 52: 201-220.

Levin, D. A. (2002): The Role of Chromosomal Change in Plant Evolution. Oxford University Press. UK.

Lopez, G., B. M. Potts, G. D. Dutkowsky and J. M. TraVERSO (2001): Quantitative Genetics of Eucalyptus globulus: Affinities of Land Race and Native Stands Localities. Silvae Genetica 50: 244-252.

Matsumoto, S. T., M. A. Marin-Morales, C. F. Ruas and P. M. RuAs (2000): Cytogenetic Analysis of seven species of Eucalyptus L'Her. (Myrtaceae). Caryologia. 53: $205-212$.

McAulay, A. L., F. D. Cruickshank and R. G. Barret (1936): Chromosome number of Eucalyptus globulus and Eucalyptus Johnstoni. Nature 138: 550.

McAulay, A. L. and F. D. Cruickshank (1937): The Male Meiotic Cycle in the Genus Eucalyptus. Paper \& Proc. Roy. Soc. Tasmania: 41-44.

Mora, F., C. Palma-Rojas and P. J. Seguel (2005): Comparación del cariotipo de Eucalyptus globulus y Eucalyptus cladocalyx (Myrtaceae). Agricultura Técnica 65: 20-25.

Poke, F. S., D. P. Martin, D. A. Steane, R. Vaillancourt, and J. B. REID (2006): The impact of intragenetic recombination on phylogenetic reconstruction at the sectional level in Eucalyptus when using a single copy nuclear gene (cinnoanyl CoA reductase). Molecular Phylogenetics and Evolution 39: 160-170.

PotTs, B. M. and G. M. JoRdAN (1993): Variation in a base population trial of Eucalyptus globulus subsp. globulus in Tasmania. RWG1, Forest Genetics. Camberra.

Potts, B. M., R. Vaillancourt, G. Jordan, G. Dutkowsky, J. Da Costa, E. Silva, G. McKinnon, D. Steane, P. VolKer, G. Lopez, L. Apiolaza, Y. Li, C. Marquez and N. Borralho (2004): Exploration of Gene Pool of Eucalyptus globulus. Proceedings of Simposium IUFRO. Eucalyptus in a changing the world. Aveiro, Portugal.

PRYOR, L. D. (1976): The Biology of Eucalyptus. The Institute of Biology's. Studies in Biology $\mathrm{N}^{\circ}$ 61. Edward Arnold. A clasification of the Eucalyptus. Australian National University Press. Camberra.

RYE, B. L. (1979): Chromosome Number Variation in the Myrtaceae and its Taxonomic Implications. Austral. J. Bot. 27: 547-573.

ReEves, A. (2001): MicroMeasure: a new computer program for the collection and analysis of cytogenetic data. Genome 44: 239-443.

SANHUEZA, R. and A. R. GRIFFIN (2001): FAMASA Fiber Yield Improvement Programme "FYIP": Ten Years Experience Breeding Eucalyptus globulus. Actas del Simposio IUFRO, "Desarrollando el Eucalypto para el Futuro", Valdivia Chile

Schrader, O., H. Budahn and R. Ahne (2000): Detection of $5 \mathrm{~S}$ and 25S rRNA genes in Sinapis alba, Raphanus sativus and Brassica napus by double fluorescence in situ hybridization. Theor. Appl. Genet. 100: 665-669.

Schrader, O., R. Ahne and J. Fuchs (2003): Karyotype analysis of Daucus carota L. using Giemsa C-Banding and FISH of $5 \mathrm{~S}$ and 18/25S rRNA specific genes. Caryologia 56: 149-154.

StebBins, G. (1971): Chromosomal Evolution in Higher Plants. Contemporary Biology. Edward Arnold Ltd, London. 